\title{
ОГЛЯДИ
}

УДК 372.881.1

\section{ВИБІРКОВІ НАВЧАЛЬНІ ДИСЦИПЛІНИ 3 КУРСУ МЕТОДИКИ ДЛЯ МАЙБУТНІХ ВИКЛАДАЧІВ ІНОЗЕМНИХ МОВ}

\author{
Бігич О. Б. \\ bkbpearl@gmail.com \\ https://orcid.org/0000-0002-7997-8487 \\ Київський наиіональний лінгвістичний університет \\ Дата надходження 20.10.2020. Дата прийняття до друку 27.11.2020.
}

\begin{abstract}
Анотація. В статті описано технологію конструювання змісту вибіркових дисциплін з курсу методики навчання іноземних мов і культур, що викладаються студентам магістратури - майбутнім викладачам іноземних мов.
\end{abstract}

Ключові слова: магістратура, іноземні мови, вибіркові дисципліни.

Бигич О. Б. Киевский национальный лингвистический университет

Элективные учебные дисциплины курса методики для будущих преподавателей иностранных языков

Аннотация. В статье описана технология конструирования содержания элективных дисциплин курса методики обучения иностранным языкам и культурам, преподаваемых студентам магистратуры будущим преподавателям иностранных языков.

Ключевые слова: магистратура, иностранные языки, элективные дисциплины.

Bigych O. Kyiv National Linguistic University

Methodology elective academic courses for prospective foreign language lecturers

Abstract. The technology of designing the content of some methodology elective courses for teaching foreign languages and cultures that are taught by MA students - prospective foreign language lecturers.

Key words: master's degree, foreign languages, elective courses.

Постановка проблеми. Поява у 2016 році нової спеціальності 014 Середня освіта галузі знань 01 Освіта/ Педагогіка передбачала оновлення системи формування у студентів магістратури методичної компетентності викладача іноземної мови в контексті сучасних тенденцій його фахової іншомовної освіти. 3-поміж навчальних дисциплін, які викладаються на другому (магістерському) рівні, вагоме місце посідають професійно оріснтовані вибіркові дисципліни, зокрема 3 курсу методики навчання іноземної мови й культури.

Аналіз останніх досліджень і публікацій. Низку вибіркових навчальних дисциплін 3 курсу методики навчання іноземних мов і культур, які викладаються студентам магістратури в Київському національному лінгвістичному університеті, зокрема "Сучасні технології навчання іноземних мов і культур" й “Інноваційні підходи до навчання іноземних мов і культур", методично забезпечено такими засобами навчання, як авторський освітній сайт (режим доступу www.bigich.knlu.edu.ua.014.02) і навчальний посібник для самостійної роботи студентів (Бігич, 2018). 
Бігич О. Б. Вибіркові навчальні дисципліни з курсу методики для майбутніх викладачів іноземних мов

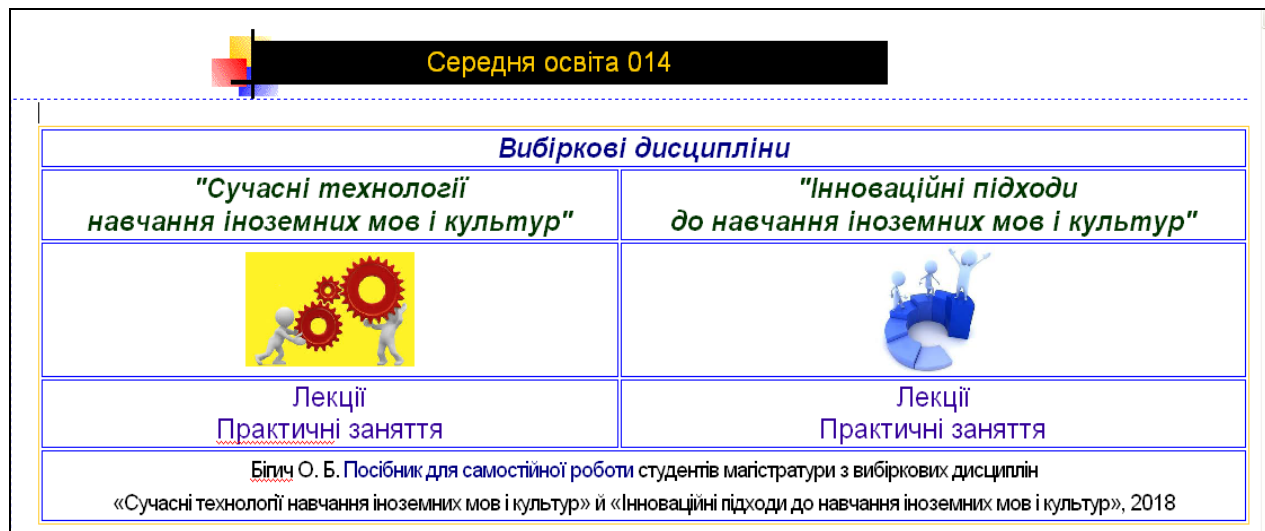

Мета статті - описати технологію конструювання змісту вибіркових дисциплін з курсу методики навчання іноземних мов і культур, які викладаються студентам магістратури у Київському національному лінгвістичному університеті

Виклад основного матеріалу. Вибіркові дисципліни з курсу методики навчання іноземних мов і культур, як обов'язкові навчальні дисципліни за вибором студентів, виконують низку функцій: 1) слугують своєрідною “надбудовою” фахової дисципліни “Методика навчання іноземної мови і культури в європейському контексті в закладах вищої освіти”, яка через доповнення стає поглибленою, 2) розвивають зміст фахової дисципліни "Методика навчання іноземної мови і культури в європейському контексті в закладах вищої освіти”, 3) сприяють задоволенню пізнавальних інтересів студентів магістратури - майбутніх викладачів іноземних мов.

За типологією вибіркових дисциплін, пропонованою Г. А. Роговою (Рогова), вибіркові дисципліни з курсу методики навчання іноземних мов і культур є предметними вибірковими дисциплінами, завдання яких - поглиблення й розширення предметних, зокрема методичних знань, й удосконалення методичних навичок як складників методичної компетентності викладача іноземної мови.

Результативність вибіркових дисциплін досягається за умови, що студенти мають можливість їх свідомого вибору. Для обгрунтування свого вибору студенти мають чітко усвідомлювати свої методичні інтереси й плани, повинні мати можливість попередньо ознайомитись зі змістом, зокрема короткими анотаціями, пропонованих вибіркових дисциплін, а також їхніми презентаціями, підготовленими викладачами.

Основною особливістю вибіркових дисциплін $є$ їхня варіативність, що надає студенту можливість вільного вибору індивідуальної освітньої траєкторії з перспективою його подальшого методичного розвитку.

“Методика навчання іноземної мов і культур" є навчальною дисципліною з провідним складником “способи діяльності”. В контексті компетентнісного підходу саме досвід творчої діяльності студентів - майбутніх викладачів іноземних мов - слугує провідним складником конструювання змісту вибіркових дисциплін, оскільки через набуття студентом досвіду розвивається його ціннісне ставлення до об'єктів світу, зокрема до професії. Свідомий вибір майбутньої освітньо-професійної траєкторії спрямований на формування ставлення до професії. Сформований досвід творчої діяльності уможливлює формування емоційно-ціннісного ставлення студентів до професії викладача іноземної мови, яке визначає їхню готовність до вирішення професійних проблем і завдань. У такий спосіб досвід творчої діяльності студентів і досвід їхнього емоційно-ціннісного ставлення до професії слугують підгрунтям формування методичної компетентності викладача іноземної мови. 
Конструювання змісту вибіркових дисциплін з курсу методики навчання іноземних мов і культур передбачає розроблення й деталізацію системи методичних знань студентів, їхнього досвіду практичної й творчої діяльності, ціннісного ставлення до об' єктів світу та визначення взаємозв'язків між ними задля забезпечення цілісності й цілеспрямованості вибіркової дисципліни. Технологія конструювання змісту вибіркових дисциплін $є$ діяльністю викладача щодо вирішення завдань і досягнення результатів на кожному з етапів: аналітичному, конструктивному, оцінювальному й етапі експертизи.

На аналітичному етапі викладач вивчає освітні запити студентів, визначає мету вибіркової навчальної дисципліни, встановлює взаємозв'язки між змістом фахової дисципліни “Методика навчання іноземної мови і культури в європейському контексті в закладах вищої освіти" й можливостями вибіркової дисципліни, унаслідок чого укладає пояснювальну записку та формулює мету й завдання вибіркової дисципліни.

На конструктивному етапі викладач розробляє зміст вибіркової дисципліни: визначає й перераховує іiї провідні поняття, обирає форми організації занять, укладає список джерел, зокрема електронних, розробляє фонд творчих завдань, укладає тематику методичних проєктів тощо. Унаслідок виокремлюються основні поняття вибіркової дисципліни, здійснюється тематичне планування, укладається контент лекцій і розробляються плани практичних занять, укладаються / добираються завдання для індивідуальної роботи студента й творчі завдання.

Оцінювальний етап передбачає визначення форм і методів оцінювання результативності засвоєння студентами змісту вибіркової дисципліни. Викладач розробляє форми поточного, проміжного й підсумкового контролю, окреслює вимоги до результатів засвоєння вибіркової дисципліни та критерії їх оцінювання. Унаслідок укладасться пакет контрольно-вимірювальних матеріалів та критерії оцінювання засвоєння змісту вибіркової дисципліни.

Етап експертизи покликаний визначити якість сконструйованої програми вибіркової дисципліни та встановити відповідність змісту ії програми фаховим цілям і потребам студентів. Викладач діагностує вплив змісту вибіркової дисципліни на академічні й творчі досягнення студентів та анкетує їх задля виявлення ступеня їхньої задоволеності змістом вибіркової дисципліни.

Критеріями результативності технології конструювання змісту вибіркової дисципліни слугують особистісно-смислове ставлення студента до її змісту, сформованість способів пізнання та сформованість досвіду творчої діяльності студента.

Показниками результативності технології конструювання змісту вибіркової дисципліни за критерієм особистісно-смислового ставлення студента до їі змісту є його інтерес до змісту фахової дисципліни "Методика навчання іноземної мови і культури в європейському контексті в закладах вищої освіти", обгрунтування свого професійного вибору, різновиди навчальної діяльності, в яких студент брав участь.

Показниками результативності технології конструювання змісту вибіркової дисципліни за критерієм сформованості у студентів способів пізнання $є$ низка вмінь: укладати план дослідження, аналізувати джерела, визначати проблему та формулювати іiі, аргументувати точку зору, використовувати зміст різних навчальних дисциплін при вирішенні однієї проблеми.

Показниками результативності технології конструювання змісту вибіркової дисципліни за критерієм сформованості у студентів досвіду творчої діяльності є вміння пропонувати декілька способів вирішення одного завдання / проблеми, вміння пропонувати обговорення / доказ у нетрадиційній логіці, вміння планувати й організовувати дослідження.

У вибіркових навчальних дисциплінах "Інноваційні підходи до навчання іноземних мов і культур”, “Сучасні технології навчання іноземних мов і культур" та "Електронні засоби навчання іноземних мов і культур” конкретизуються такі складники системи навчання іноземних мов і культур у закладі вищої освіти, як підходи до навчання, технології й засоби навчання іноземних мов і культур. 
Так, у вибірковій дисципліні "Інноваційні підходи до навчання іноземних мов і культур" конкретизується методика формування у студентів закладів вищої освіти іншомовної комунікативної компетентності в контексті інноваційних підходів до навчання іноземних мов і культур. Зміст навчальної дисципліни розкривається в двох змістових модулях. У першому модулі представлено типологію класичних, сучасних й інноваційних підходів до навчання іноземних мов і культур. У другому модулі - різновиди професійно орієнтованого й культуро орієнтованого підходів до навчання іноземних мов і культур.

У вибірковій дисципліні "Сучасні технології навчання іноземних мов і культур" конкретизується методика формування у студентів закладів вищої освіти іншомовної комунікативної компетентності з використанням сучасних технологій навчання іноземних мов і культур. Зміст навчальної дисципліни розкривається у трьох змістових модулях. У першому модулі представлено типологію педагогічних технологій, зокрема типи технологій навчання іноземних мов і культур на засадах гуманної особистісної орієнтації процесу навчання. У другому модулі - типи технологій навчання іноземних мов і культур на засадах активізації й інтенсифікації навчальної діяльності та ефективності управління й організації процесу навчання. У третьому модулі - типи технологій навчання іноземних мов і культур на засадах дидактичного вдосконалення й реконструювання навчального матеріалу та в межах альтернативних педагогічних технологій.

У такий спосіб студенти, обравши ці дві вибіркові дисциплін, мають можливість конкретизувати методичні знання про такі складники системи навчання іноземних мов і культур у закладі вищої освіти, як інноваційні підходи до навчання та сучасні технології навчання.

У вибірковій дисципліні “Психолого-педагогічні аспекти навчання іноземних мов і культур у закладах вищої освіти” конкретизується методика формування у студентів закладів вищої освіти іншомовної комунікативної компетентності в контексті особистісно-діяльнісного підходу. Зміст навчальної дисципліни розкривається в двох змістових модулях. У першому модулі представлено психологічні аспекти навчання іноземних мов і культур, зокрема технологій індивідуалізованого й диференційованого навчання. У другому модулі - педагогічні аспекти навчання іноземних мов і культур, зокрема технології інтерактивного навчання.

У такий спосіб студенти, обравши цю вибіркову дисципліну, мають можливість конкретизувати методичні знання про індивідуалізоване, диференційоване й інтерактивне навчання іноземних мов і культур як сучасні технології навчання, реалізовані в контексті особистісно-діяльнісного підходу.

Вибіркову дисципліну “Гейміфікація навчання іноземних мов і культур у закладах вищої освіти” запропоновано студентам з огляду на такі чинники. Передусім з-поміж сучасних технологій навчання іноземних мов і культур найзапитанішими як викладачами, так і студентами-практикантами $\epsilon$ саме ігрові технології. По-друге, залучення гри до процесу навчання іноземної мови $є$ однією з характерних ознак такої сучасної технології навчання, як ед’ютеймент. По-третє, традиційна настанова “Let’s play” чи “Vamos a jugar” ще не робить вправу чи завдання ігровими. Студенти-практиканти мають знати про різновиди ігор для навчання іноземних мов і культур, про структуру рольової гри, про складники навчальнокомунікативної ситуації тощо.

У вибірковій дисципліні “Гейміфікація навчання іноземних мов і культур у закладах вищої освіти” конкретизується методика формування у студентів закладів вищої освіти іншомовної комунікативної компетентності засобом різних видів ігор. Зміст навчальної дисципліни розкривається в двох змістових модулях. У першому модулі представлено ігри для проведення на аудиторних заняттях з іноземної мови, в другому модулі - ігри для проведення під час самостійної (позааудиторної) роботи студентів з іноземної мови. 
У такий спосіб студенти, обравши цю вибіркову дисципліну, мають можливість конкретизувати методичні знання про ігровий формат пропонованих вправ і завдань для формування у студентів іншомовної комунікативної компетентності під час аудиторної та позааудиторної самостійної роботи.

Вибірковій дисципліні “Електронні засоби навчання іноземних мов і культур”, в якій конкретизується методика формування у студентів закладів вищої освіти іншомовної комунікативної компетентності з використанням електронних засобів навчання, в бакалавраті передувала вибіркова дисципліна “Сучасні засоби навчання іноземної мови в закладі середньої освіти”. Відповідно студенти вже знайомі із сучасними засобами навчання іноземної мови. Зміст навчальної дисципліни “Електронні засоби навчання іноземних мов і культур” розкривається у трьох змістових модулях. У першому модулі представлено типологію електронних засобів навчання іноземних мов і культур. У другому модулі конкретизуються електронні засоби навчання, які використовує викладач у своїй професійній діяльності, в третьому модулі електронні засоби навчання, призначені для самостійної роботи студента.

У такий спосіб студенти, обравши цю вибіркову дисципліну, мають можливість конкретизувати методичні знання про електронні засоби формування іншомовної комунікативної компетентності як на аудиторних заняттях, так і під час самостійної позааудиторної роботи.

3 огляду на такі особливості сучасного студентства - покоління центеніалів як важкість сприймання ними навчальної інформації на слух і, відповідно, обов'язкову візуалізацію навчального матеріалу, запропоновано вибіркову дисципліну “Візуальні опори для навчання іноземних мов і культур". Зміст навчальної дисципліни розкривається у трьох змістових модулях. У першому модулі представлено типологію візуальних опор, зокрема ілюстративні опори для навчання іноземних мов і культур. У другому модулі - вербальні опори для навчання іноземних мов і культур. У третьому модулі - комбіновані опори для навчання іноземних мов і культур.

У такий спосіб студенти, обравши цю вибіркову дисципліну, мають можливість конкретизувати методичні знання про візуальні опори для формування у студентів закладів вищої освіти іншомовної комунікативної компетентності.

Висновки і перспективи подальших розвідок. Таким чином, осучаснення складників системи професійно орієнтованої іншомовної освіти студентів закладів вищої освіти зумовило конструювання змісту низки вибіркових дисциплін з курсу методики навчання іноземних мов і культур, що викладаються студентам магістратури - майбутнім викладачам іноземних мов: “Інноваційні підходи до навчання іноземних мов і культур”, “Сучасні технології навчання іноземних мов і культур”, “Електронні засоби навчання іноземних мов і культур”, "Психологопедагогічні аспекти навчання іноземних мов і культур у закладах вищої освіти”, “Гейміфікація навчання іноземних мов і культур у закладах вищої освіти”, "Візуальні опори для навчання іноземних мов і культур”. Визначення мотивів, якими керуються студенти магістратури, обираючи ту чи іншу вибіркову дисципліну, й складатиме предмет подальшої наукової розвідки.

\section{ЛІТЕРАТУРА}

Бігич, О. Б. (2018). Посібник для самостійної роботи студентів магістратури з вибіркових дисииплін "Сучасні технології навчання іноземних мов і культур" й "Інновачійні підходи до навчання іноземних мов і культур”. Київ: Видавничий центр КНЛУ.

Рогова, Г. А. Элективные курсы как содержательная основа профильного обучения. Вопросы Интернет образования, 56. Взято из http://vio.uchim.info/Vio_58/cd_site/articles/ art_4_7.htm.

\section{REFERENCES}

Bihych, O. B. (2018). Posibnyk dlia samostijnoi roboty studentiv mahistratury z vybirkovykh dystsyplin "Suchasni tekhnolohii navchannia inozemnykh mov i kul'tur" $\mathrm{j}$ "Innovatsijni pidkhody do navchannia inozemnykh mov i kul'tur". Kyiv: Vydavnychyj tsentr KNLU.

Rohova, H. A. Elektyvnye kursy kak soderzhatel'naia osnova profyl'noho obuchenyia. Voprosy Ynternet obrazovanyia, 56. Vziato yz http://vio.uchim.info/Vio_58/cd_site/articles/art_4_7.htm. 